九州大学学術情報リポジトリ

Kyushu University Institutional Repository

\title{
Field Measurement of Indoor Thermal Environment of a Retrofitted Ger in Ulaanbaatar, Mongolia
}

Purev, Uelun-Ujin

Interdisciplinary Graduate School of Engineering Science, Kyushu University

Hagishima, Aya

Interdisciplinary Graduate School of Engineering Science, Kyushu University

https://doi.org/10.5109/4738589

出版情報: Proceedings of International Exchange and Innovation Conference on Engineering \& Sciences (IEICES). 7, pp.204-209，2021-10-21. 九州大学大学院総合理工学府 バージョン :

権利関係 : 


\title{
Field Measurement of Indoor Thermal Environment of a Retrofitted Ger in Ulaanbaatar, Mongolia
}

\author{
Uelun-Ujin Purev $^{1 *}$, Aya Hagishima ${ }^{1}$ \\ ${ }^{1}$ Interdisciplinary Graduate School of Engineering Science, Kyushu University, Japan \\ *Corresponding author email: ujin@kyudai.jp
}

\begin{abstract}
In this study, the walls and roofs of five-walled gers were insulated with high-performance building insulation materials while maintaining the original purpose of portable design of the ger. The ger is a traditional nomadic housing made of wooden structures and covered with few layers of felt sheets. In Ulaanbaatar, 30.4\% of the total households live in gers. The indoor air temperature, surface temperature, outdoor air temperature, and solar radiation were measured to validate the performance of roof and wall retrofitting. Measurements were performed in two phases: before and after renovation. After renovation, the wall surface temperature increased and became similar to the roof surface temperature. The floor surface temperature remained low, from $0{ }^{\circ} \mathrm{C}$ to $15{ }^{\circ} \mathrm{C}$, indicating that floor insulation was needed. The operative temperature was up to $5{ }^{\circ} \mathrm{C}$ higher than the indoor air temperature before renovation, and after renovation, the operative temperature become $1.5^{\circ} \mathrm{C}$ higher than the indoor air temperature owing to the use of an electric heating device.
\end{abstract}

Keywords: ger; operative temperature; field measurement; retrofitting

\section{INTRODUCTION}

In recent years, Ulaanbaatar, the capital city of Mongolia, located in the northern part of East Asia, has suffered from the world's worst air pollution during winter [1]. According to Soluyanov et al. [2], approximately $80 \%$ of the source of air pollutants in Ulaanbaatar are emissions from coal-burning stoves used for space heating in lowcost detached houses located in ger districts, which have rapidly expanding unplanned residential districts with insufficient urban infrastructure such as water, sewage, and heating. A ger refers to traditional portable tents for nomadic people made of wooden poles covered with felted wool sheets. In Ulaanbaatar, $58 \%$ of the total households live in ger districts, and $52 \%$ of these households live in gers; in contrast, in 2016, $48 \%$ lived in self-built detached houses named baishin [3] Because of the cold climate with temperature below $-40{ }^{\circ} \mathrm{C}$ in winter, space heating is indispensable, and the majority of both gers and baishins located in ger districts currently use coal stoves. The large contribution of these coal stoves to the severe air pollution in Ulaanbaatar is because of not only the cold climate but also the low insulation envelopes of both gers and baishins.

The negative effects of poorly insulated houses and the coal stoves used in them are not confined to severe air pollution in Ulaanbaatar. For example, energy inefficiency in the space heating of such dwellings contributes to high fossil fuel consumption and greenhouse gas emissions. The building and energy sectors are responsible for $50 \%$ of greenhouse gas emissions in Mongolia. Therefore, in 2016, the Mongolian government set a target to reduce building heat loss by $40 \%$ by 2030 [4] in response to the Paris Agreement on Climate Change.

Indoor air pollution and the resulting health risks are also major concerns with the coal stoves used in housing. The World Health Organization has highlighted the significant health risks of indoor air pollution from the use of fuel stoves in developing countries and has emphasised the need for countermeasures [5].

With this background, the government subsidised the replacement of approximately 40,000 conventional coal stoves used in ger districts with energy-efficient stoves with lower emissions between 2011 and 2015 [6]. In addition, a pilot project that encourages the use of electric heaters in ger districts and the utilisation of excess overnight electricity by subsidising a part of the electricity bill was conducted in 2017. Furthermore, an insulation subsidy program for households living in baishin has been implemented since 2017 under the clean air project with support from the World Bank and Asian Development Bank [6].

Considering the large share of households living in gers $(30.4 \%)$ [3] and the current power supply capacity in Ulaanbaatar, policies to promote the use of electric heaters in ger housing should be implemented in conjunction with policies to improve the thermal insulation performance of ger envelopes. However, to our knowledge, there have been no attempts to improve the thermal performance of the gers.

A few studies have reported on the thermal performance and indoor thermal conditions of current ger housing. For example, Ishikawa et al. [7] measured the indoor air temperature of six gers and revealed a large temperature difference according to the height, probably due to the low airtightness of the ger envelopes. Buyantogtokh and Zhang [8] measured the indoor thermal conditions of 10 gers and estimated the infiltration rate and heat loss coefficients. Both studies highlighted the weak insulation performance of ger envelopes; however, research to improve the low thermal performance of gers has not been conducted.

Under these circumstances, the authors aimed to develop a new method for improving the insulation performance of ger envelopes which is fully tailored to the local contexts, including the economic status, construction methods, and available materials, thus making it affordable for a wide range of households living in Ulaanbaatar. This paper describes a method developed based on the requirements for improving the thermal insulation of gers. The results of the demonstration test of the developed method are also presented.

\section{DEVELOPED RETROFITTING METHOD}

\subsection{Design and materials of gers}

A ger has a single round space with a wooden structure covered with few layers of felt sheets. The design of gers, including the materials, structure, and size of each part, is well standardised based on the Mongolian Agency for Standardisation [9]. Figures 1 and 2 show the exterior 
view and the section and floor plans, respectively, of a typical ger which we surveyed during the demonstration test. The circular wall of the gers comprises multiple wood lattice components and is easily folded. The number in the name "five-walled ger" refers to the number of these lattice components, and the higher the number, the larger is the floor space of a ger. The fivewalled gers with a floor area of approximately $30.9 \mathrm{~m}^{2}$ account for the majority in Ulaanbaatar [9].

Gers can be easily assembled and disassembled by two to four adults within a few hours. According to a questionnaire survey conducted by Purev and Hagishima [10], most people living in urban gers partially reassemble their gers approximately twice a year in order to dry the felt sheets, to add more felt sheets, or to improve the airtightness between various components for severe winters.

The interior space of most gers can be classified into several functional zones by furniture, and the layout of furniture is relatively similar among households. In particular, a stove is almost always placed in the centre of a $g e r$.

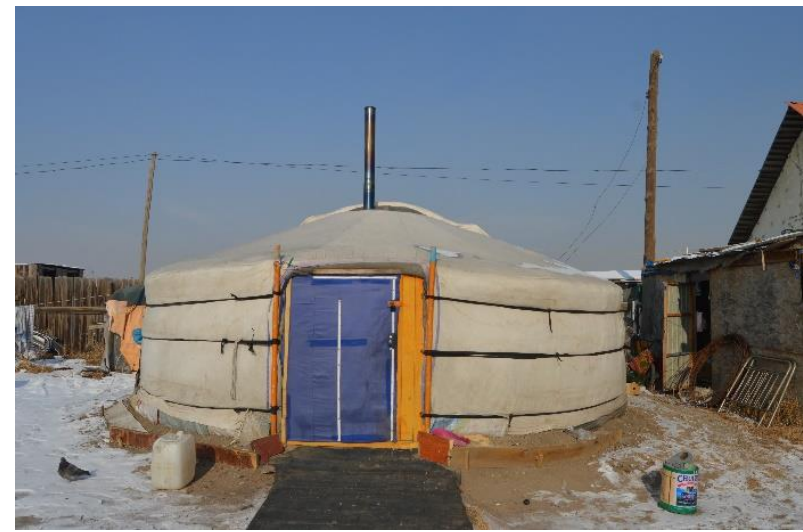

Fig. 1. Exterior view of a typical five-walled ger

\subsection{Required conditions for improving insulation performance of $\mathrm{gers}$}

Gers are affordable local accommodations for lowincome households in Ulaanbaatar. Purev and Hagishima [10] reported that the average market price of five-walled gers ranged from MNT 2,200,000 to MNT 2,500,000, which was equivalent to three- or four-month household income of ger residents. In contrast, the average cost of apartment dwellings is approximately 14 times the annual income of households living in urban areas. Therefore, one of the major constraints in designing a new insulation prototype is that the prices should be low enough that residents already accustomed to the low cost of gers will be willing to invest in it. Thus, it is necessary to utilise locally available and inexpensive materials. In addition, the main structure of the ger is portable; hence, the insulation prototype must also be portable.

\subsection{Developed method}

As can be seen from the right half of Figure 2, the authors adopted a method to add an insulation layer on the inner surface of the wall and roof of a ger. To cover the curved wall and conical roof surfaces with inexpensive flat insulation boards, an insulation layer for both the wall and roof was divided into 20 sections in the circumferential direction and connected, as shown in Figure 3.
The roof panels were made of rolled glass wool wrapped in fireproof fabric. The estimated total weight of all roof panels is $80 \mathrm{~kg}$. In contrast, wall panels were made of an expanded polystyrene board with a depth of $50 \mathrm{~mm}$ covered by a waterproof tent fabric. These panels were attached to the beams and lattices with strings. In addition, the panels were joined with hook and loop tapes to reduce air leakage through the gap between the panels. Furthermore, the skylight was covered by two semicircular panels of rolled glass wool with a depth of approximately $50 \mathrm{~mm}$ wrapped by waterproof fabric. The $\mathrm{U}$ value of the ger envelope with developed insulation panels was estimated to be $0.5 \mathrm{~W} / \mathrm{m}^{2} \mathrm{~K}$ and $0.4 \mathrm{~W} / \mathrm{m}^{2} \mathrm{~K}$ for the roof and wall, respectively. a)

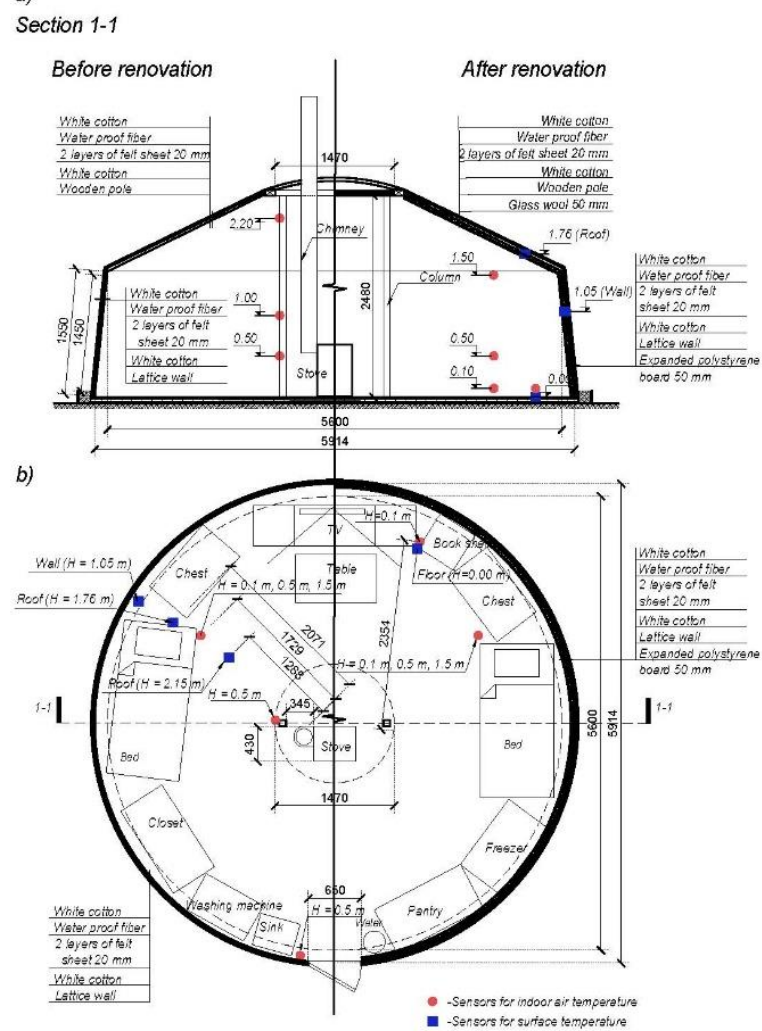

Fig. 2. (a) Cross-sectional view and (b) floor plan of a five-walled ger. Measurement positions of temperature in the demonstration test are also included.

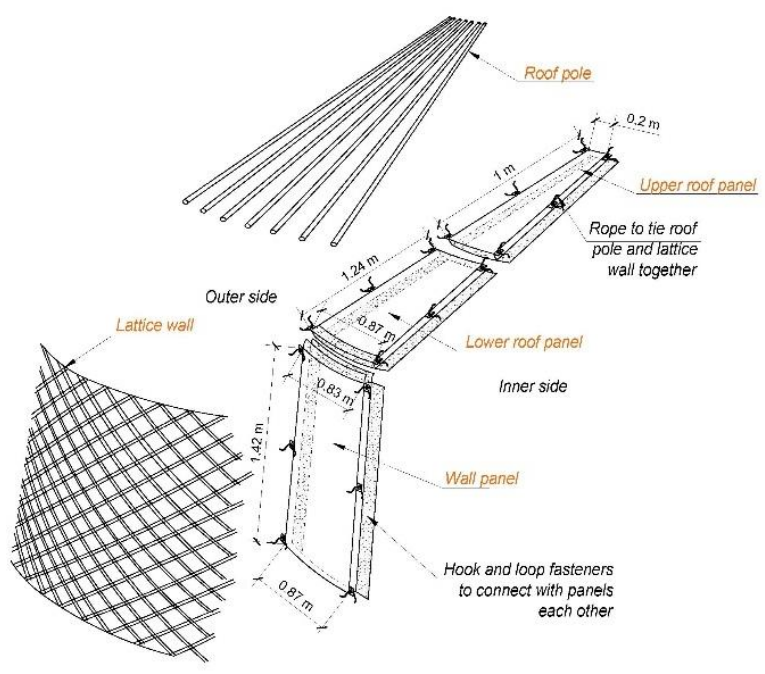

Fig. 3. Detail of the developed insulation panels 
In contrast, the $\mathrm{U}$ value of a standard ger with two felt sheets is reported as $1.8 \mathrm{~W} / \mathrm{m}^{2} \mathrm{~K}$.

The designed insulation system consisted of materials available in local markets for construction materials and was prototyped by a local small sewing company. The costs for materials and sewing were approximately MNT 1,200,000 and MNT 700,000, respectively. Because the weight of each panel is less than $3 \mathrm{~kg}$, the installation of these panels can be completed within a few hours with two adults working. In other words, this insulation system can be introduced at a reasonable cost of approximately $76 \%$ of the price of a ger itself.

\subsection{Expected reduction in heating demand}

Neglecting the heat loss on the floor, the annual heating load [Wh] of a baseline ger was estimated as follows:

$$
H=\left(A U_{b}+\rho c_{p} Q\right) \cdot D H \quad(1) .
$$

$U_{\mathrm{b}}$ is the thermal transmittance $\left(\mathrm{Wm}^{-2} \mathrm{~K}^{-1}\right)$ of the envelope of a baseline ger. $A$ is the surface area $\left(\mathrm{m}^{2}\right)$ of the ger envelope. $\rho$ and $\mathrm{c}_{\mathrm{p}}$ are the density $\left(\mathrm{kg} \mathrm{m}^{-3}\right)$ and specific heat $\left(\mathrm{J} \mathrm{kg}^{-1} \mathrm{~K}^{-1}\right)$ of the air, respectively. $Q$ is the ventilation rate $\left[\mathrm{m}^{3} \mathrm{~s}^{-1}\right] . D H$ is the degree hours determined as follows:

$$
D H=\sum_{t}\left(T_{\text {set }}-T_{\text {out }, t}\right) \text { for }\left(T_{\text {set }} \geq T_{\text {out }, t}\right)
$$

$T_{\text {set }}$ is the indoor air temperature during the heating period, and $T_{\text {out, } t}$ is the hourly outdoor air temperature. $t$ is time step with an interval of 1 hour for all the year Based on the observed weather data in 2019 provided by the National Climatic Data Centre, USA [11], $D H$ was 8730 under the assumption of $\mathrm{T}_{\text {set }}=18.5^{\circ} \mathrm{C}$.

The expected annual reduction in the thermal load of a ger $\Delta \mathrm{H}[\mathrm{Wh}]$ owing to the proposed insulation system can thus be calculated using Equation (3).

$$
\Delta H=A\left(U_{b}-U_{r}\right) \cdot D H
$$

where $U_{\mathrm{r}}$ is the thermal transmittance $\left(\mathrm{Wm}^{-2} \mathrm{~K}^{-1}\right)$ of a renovated ger. Based on the standard thermal properties used for a ger envelope and insulation panels proposed, $U_{\mathrm{b}}$ and $U_{\mathrm{r}}$ were estimated as $7.5 \mathrm{Wm}^{-2} \mathrm{~K}^{-1}$ and $2.2 \mathrm{Wm}^{-}$ ${ }^{2} \mathrm{~K}^{-1}$, respectively. This indicates that the heat loss through the envelope can be decreased by $72 \%$ for a fivewalled ger by introducing the proposed insulation system. Moreover, a recent survey conducted in 2018 suggested that the annual cost of coal used in urban gers ranged from 375,000 to 500,000 MNT [10][12]. Assuming the scenario that a heating device is shifted from a coal stove to electric heaters in a current ger as a countermeasure of indoor and outdoor air pollution, the annual electricity bill is estimated at 3.4 million MNT, which is $85 \%$ higher than the current cost for coal stove heating. However, by introducing the proposed insulation panels, the annual electricity cost can be reduced to approximately 1 million MNT.

\section{OUTLINE OF DEMONSTRATION TEST}

\subsection{Details of surveyed ger}

A prototype of the developed insulation system was installed at a typical five-walled ger located in Songinokhairkhan district, Ulaanbaatar, Mongolia, from 24 January 2020 to 6 February 2020 for 13 days. Data for
28 January are excluded because both the stove and electric heater were used on this day. In addition to the developed insulation system, electric heaters were installed in the centre of the ger as a substitute for a coal stove.

During this period, two elderly people resided in this ger, as usual. The authors often interviewed the occupants regarding their impressions of the developed system, including psychological and functional aspects.

The ger was built 8 years ago at the current site. The original envelope of the ger consisted of an outer thin white fabric, a waterproofed sheet to prevent rain leakage, two layers of felted wool sheets, and a white fabric for indoor aesthetics. Felt sheets have been used for approximately 40 years. The wooden door was covered by one layer of felt sheet by the occupants to reduce heat loss during winter. The floor was made of 20 mm thick wooden boards covered with laminate, which were placed on bare soil. The skylight was made of a thin polyethylene plate, and half of the skylight was covered by two layers of felt sheets from the outside.

\subsection{Measurement of indoor thermal condition}

The indoor thermal conditions of the ger with and without the developed insulation system were measured. The measurement term is classified into two phases: 1) from 24 to 27 January 2020 as the baseline condition before renovation, and 2) from 29 January 2020 to 6 February 2020 as the period with insulation renovation. During the measurement period, the temperatures of the indoor air and envelope surface were monitored at eight and three locations, respectively, every minute. In addition, the outdoor air temperature and solar radiation were recorded at a height of $2 \mathrm{~m}$ near the ger. Table 1 lists the instruments used in these measurements.

\section{RESULTS OF THE DEMONSTRATION TEST 4.1 Indoor air temperature}

Figure 4 shows the time variations in the indoor and outdoor air temperatures and global solar radiation. The energy consumption of a coal stove estimated before the renovation and electricity consumption of convection heaters after renovation is also included. During the measurement period, the outdoor temperature ranged from $-30{ }^{\circ} \mathrm{C}$ to $-3{ }^{\circ} \mathrm{C}$. The almost symmetric diurnal variation of solar radiation indicates continuous clear-sky conditions.

Regarding the indoor air temperature before the renovation, multiple peaks occurred at different times each day, showing a completely different trend from the daily variation in outdoor air temperature. This trend is because of the unstable combustion condition of the coal stove used and the cold outside air penetrating when the door was opened by the occupants. The temperature at a height of $2.2 \mathrm{~m}$ during the peak durations exceeded $40{ }^{\circ} \mathrm{C}$ and reached a maximum of $55{ }^{\circ} \mathrm{C}$. In contrast, the temperatures at a height of $0.1 \mathrm{~m}$ were always lower than $15^{\circ} \mathrm{C}$. Such a large temperature difference between the upper and lower positions is likely caused by the low insulation performance of the ger envelope, strong radiation heating of the stove, and hot updraft above the stove owing to the buoyancy force 
Table 1. Measuring instruments

\begin{tabular}{|c|c|c|}
\hline & Sensors and loggers & $\begin{array}{l}\text { Measurement range and } \\
\text { Accuracy }\end{array}$ \\
\hline $\begin{array}{l}\text { Outdoor air temperature, } \\
{\left[{ }^{\circ} \mathbf{C}\right] \mathbf{T}_{\text {out }}}\end{array}$ & $\begin{array}{l}\text { HOBO U30 Weather Station Data logger \& Sensor S- } \\
\text { THB-M002 }\end{array}$ & $\begin{array}{l}-40{ }^{\circ} \mathrm{C} \text { to } 75{ }^{\circ} \mathrm{C} \\
\pm 0.211^{\circ} \mathrm{C} \text { over } 0{ }^{\circ} \mathrm{C} \text { to } \\
50^{\circ} \mathrm{C}\end{array}$ \\
\hline Solar radiation $\left[\mathrm{W} / \mathrm{m}^{2}\right] \mathrm{SR}$ & S-LIB-M003 Silicon Pyranometer & $\pm 10 \mathrm{~W} / \mathrm{m}^{2}$ \\
\hline $\begin{array}{l}\text { Indoor air temperature }\left[{ }^{\circ} \mathbf{C}\right] \\
\mathbf{T}_{\text {in }}\end{array}$ & $\begin{array}{l}\text { T-type thermocouple }(\phi=0.1 \mathrm{~mm})+\text { logger (HIOKI, } \\
\text { LR8432 Z2015-01) }\end{array}$ & $\begin{array}{l}-40{ }^{\circ} \mathrm{C} \text { to } 125^{\circ} \mathrm{C} \\
\pm 0.5^{\circ} \mathrm{C}\end{array}$ \\
\hline $\begin{array}{l}\text { Surface temperature }\left[{ }^{\circ} \mathbf{C}\right] \\
\mathbf{T}_{\text {surf }}\end{array}$ & $\begin{array}{l}\text { T-type Thermocouple }(\phi=0.1 \mathrm{~mm})+\text { logger (HIOKI, } \\
\text { LR8432 \& Z2015-01) }\end{array}$ & $\begin{array}{l}-40{ }^{\circ} \mathrm{C} \text { to } 125^{\circ} \mathrm{C} \\
\pm 0.5^{\circ} \mathrm{C}\end{array}$ \\
\hline $\begin{array}{l}\text { Electricity consumption } \\
{[\mathrm{kW}]}\end{array}$ & Electricity monitor $(\mathrm{OWL}+\mathrm{USB})$ & NA \\
\hline
\end{tabular}

After the insulation system and electric heaters were installed, the time patterns of indoor air temperature became more stable than during the period before renovation. This is simply because of the stable heating power of convection heaters. The gradual decrease in temperature observed from around 3:00 pm on 1 February to 10:00 am the next morning can be interpreted as an increase in the heat loss of the ger owing to the gradual decrease in outdoor air temperature under the constant heating rate of the stove. The vertical temperature difference was clearly smaller than that before renovation. In particular, the temperature difference between the height of $2.2 \mathrm{~m}$ and $1.5 \mathrm{~m}$ was more than $10{ }^{\circ} \mathrm{C}$ during peak durations before the renovation, whereas it was almost zero after the renovation. This is likely owing to the change in the heating source from the high-power radiant type generating hot plumes to the convection type operated at modest heating power.

\subsection{Surface temperature of ger envelope}

Time variations in the surface temperatures of the ger envelope before the renovation and the developed insulation system after the renovation are shown in Figure 5. In general, the time variation in each part shows a similar pattern to that of the air temperatures in the room, and the effect of the heating device is assumed to be dominant.

The temperatures of the roof and wall surfaces were almost the same after the renovation; in contrast, the roof surface temperature was higher than that of the wall surface by up to $8{ }^{\circ} \mathrm{C}$ during the peak durations. Such variation in the trend of the temperature difference between the upper and lower surfaces before and after the renovation is consistent with the observed tendency of the air temperature. The floor temperature was low, ranging between $0{ }^{\circ} \mathrm{C}$ and $15{ }^{\circ} \mathrm{C}$ during both periods. This is probably because of the strong thermal stratification of indoor air. The poor insulation performance of the slab consisting of only the wooden board might have also contributed to this low temperature. In this ger, even before this demonstration test was implemented, the occupants usually wore boots or wool indoor shoes, probably to avoid the cold sensation caused by the low temperature of both the floor surface and near-floor air.

\subsection{Operative temperature as adaptive thermal comfort index}

The operative temperature $\left(\mathrm{T}_{\mathrm{op}}\right)$ determined by Equation (4) was calculated for both periods.

$$
T_{o p}=\left(T_{r}+T_{i n-0.5}\right) / 2
$$

$\mathrm{T}_{\mathrm{in}-0.5}$ is the spatially averaged air temperature at a height of $0.5 \mathrm{~m} . \mathrm{T}_{\mathrm{r}}$ is the mean radiant temperature calculated using the measured surface temperatures and the estimated radiation energy emitted from the stove. The shape factor between a stove and a seated occupant's body was determined based on the method proposed by Dunkle [13].

The time variations in the operative temperature and indoor air temperature are shown in Figure 6.

Before renovation, the operative temperature mainly ranged between $15{ }^{\circ} \mathrm{C}$ and $30{ }^{\circ} \mathrm{C}$, except for approximately 6 hours on 24 and 25 January. In addition, the operative temperature was higher than the air temperature by up to $5{ }^{\circ} \mathrm{C}$ during the peak durations, suggesting strong radiation heating of the stove.

In contrast, the operative temperature was almost equal to room temperature. This is owing to the fact that $T_{r}$ was almost equal to $\mathrm{T}_{\text {in-0.5 }}$ as a result of the long-wave radiation emitted from the surface of the insulation panels, which was always approximately $5{ }^{\circ} \mathrm{C}$ higher than $\mathrm{T}_{\mathrm{in}-0.5}$, and from the floor surface, which was always approximately $5{ }^{\circ} \mathrm{C}$ to $8{ }^{\circ} \mathrm{C}$ lower than $\mathrm{T}_{\mathrm{in}-0.5}$.

Regarding the operative temperature after the renovation and during the time when the occupants were at their ger, the results mainly showed a range of $15{ }^{\circ} \mathrm{C}$ to $20^{\circ} \mathrm{C}$. Considering the fact that the lower limit of the The American Society of Heating, Refrigerating and AirConditioning Engineers (ASHRAE) comfort range is approximately $17.5{ }^{\circ} \mathrm{C}$, the indoor thermal condition during this demonstration test is unfortunately not satisfactory for occupants. One of the reasons for this result is that the power of the electric heater used in the demonstration test could not be sufficiently increased. Owing to the age of the old power distribution system in the ger, the electric heaters could not be operated at maximum power because of the risk of leakage and fire. In addition, regarding the insulation retrofitting system we developed, it is desirable to improve it to include floor insulation in the future. 

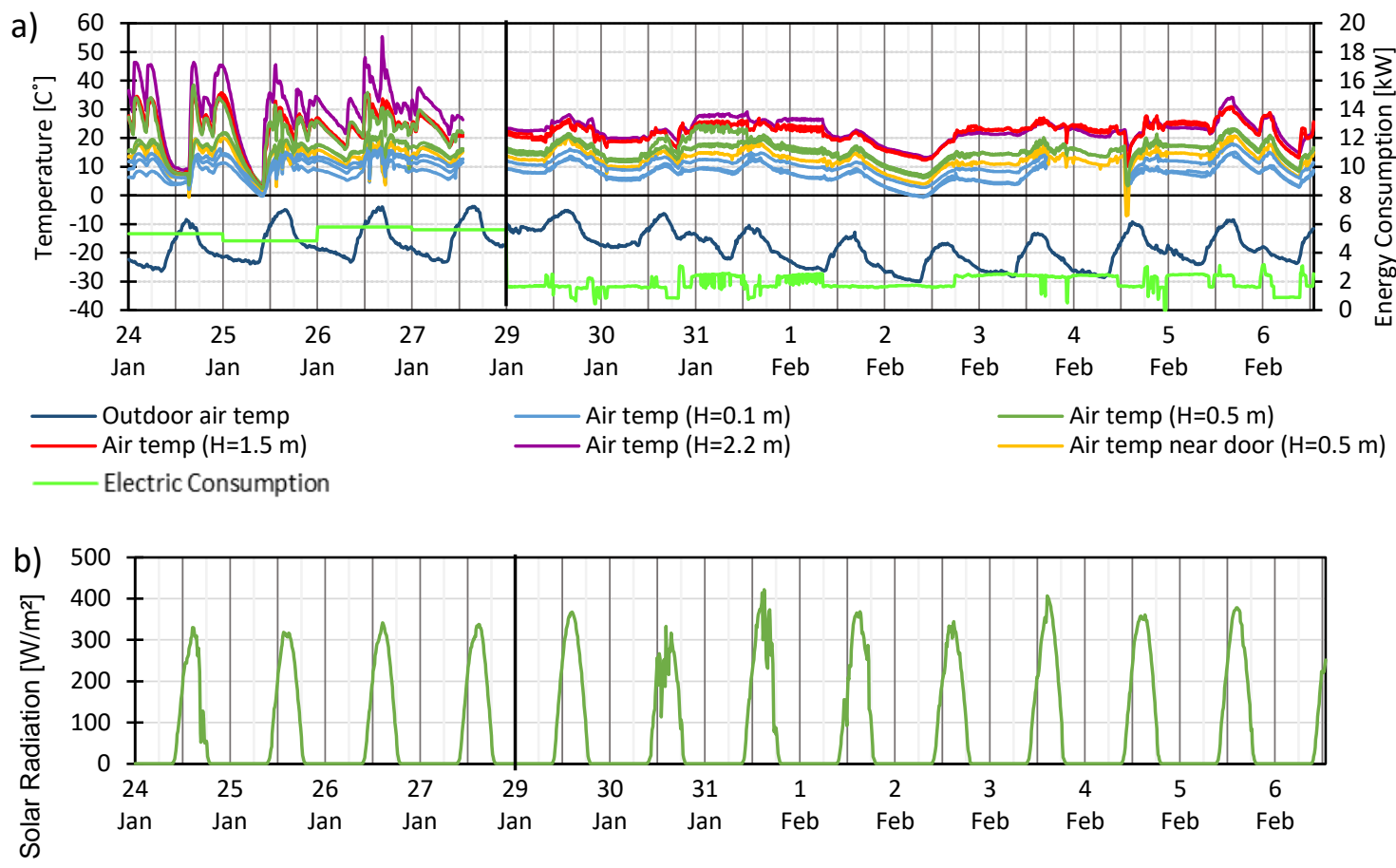

Fig. 4. Variation in measured variables over time; (a) outdoor air temperature and indoor air temperature at various heights along with electricity consumption, (b) global solar radiation

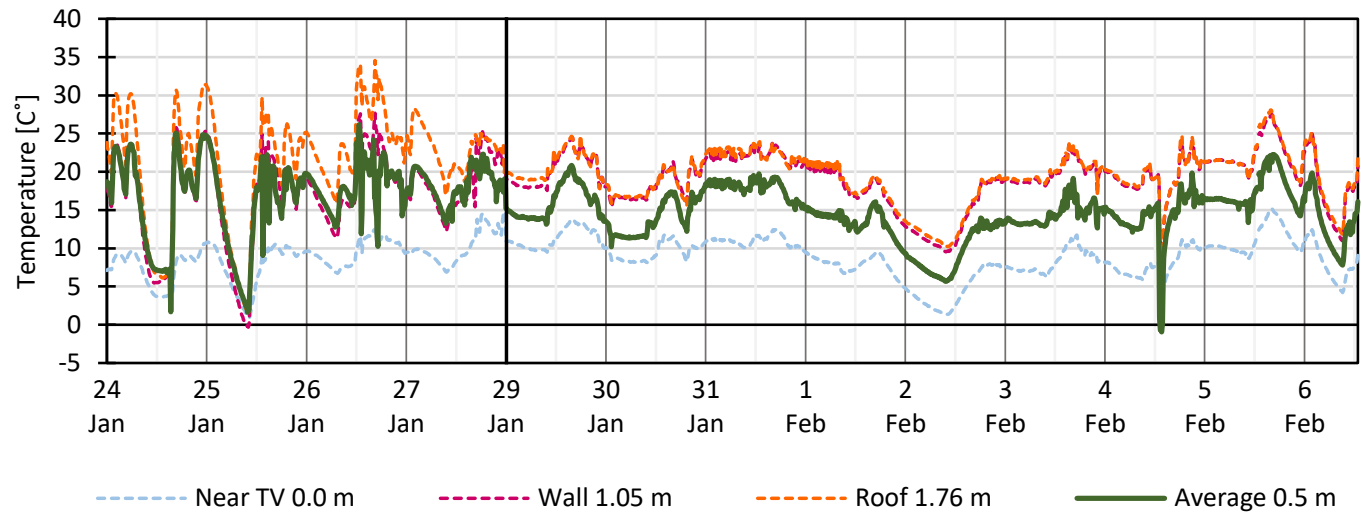

Fig. 5. Variation in surface temperature at various heights over time

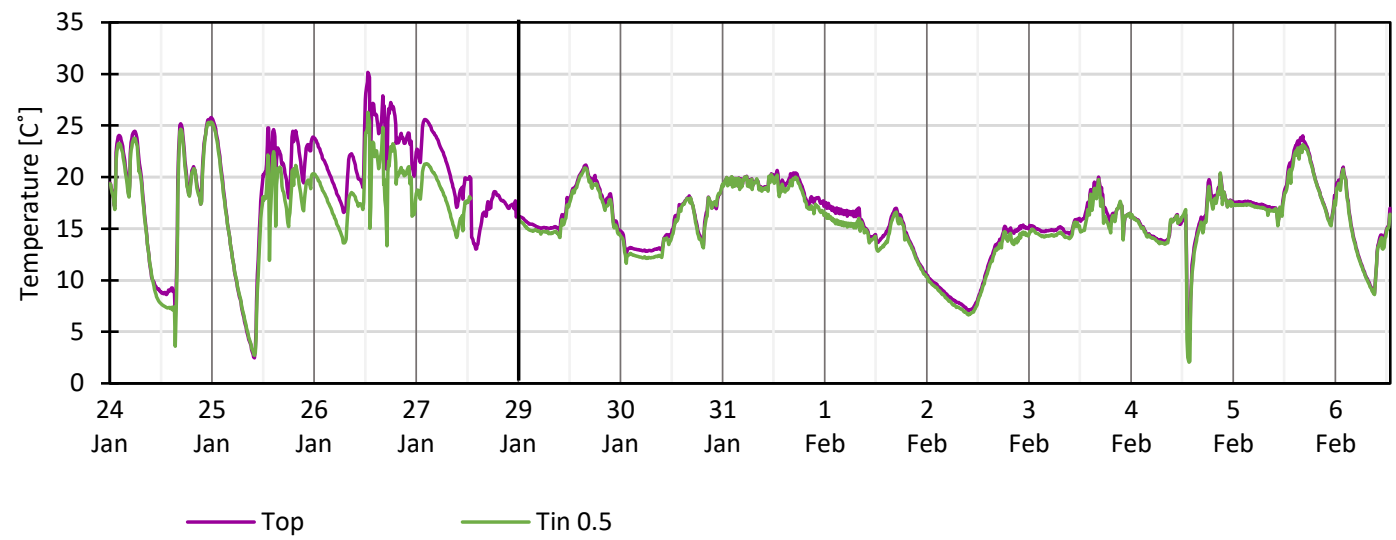

Fig. 6. Variation in operative temperature $\left(\mathrm{T}_{\mathrm{op}}\right)$ and indoor air temperature at a height of $0.5 \mathrm{~m}\left(\mathrm{~T}_{\mathrm{in}-0.5}\right)$ over time

\section{CONCLUSION}

This paper introduces the development of an affordable method to improve the thermal insulation performance of gers for urban inhabitants in Ulaanbaatar, aiming at the long-term goal of facilitating the transition from coal stoves to electric heating in urban gers, thereby mitigating the issues of air pollution and indoor air contamination. The developed system can be manufactured by local sewing companies at a low cost using locally available materials. Furthermore, it can be easily attached to the gers. A prototype of the developed 
insulation system was installed in a ger, and indoor thermal variables were observed under the conditions in which the occupants were living, and with the use of electric heaters. To promote the dissemination of this system and electric heating to urban gers in Ulaanbaatar, it would be effective to offer the service as a package that includes renewal of the ger's power distribution system and improvement in floor insulation.

\section{Acknowledgement}

This study was supported by JSPS KAKENHI (Grant Number 19K04730) and Sasakawa Scientific Research Grant from the Japan Science Society

\section{REFERENCES}

[1] UNICEF, Mongolia's air pollution crisis: A call to action to protect children' $\mathrm{s}$ health, n.d. https://www.unicef.org/mongolia/Mongolia_air _pollution_crisis_ENG.pdf.

[2] A.A. Soluyanov, D. Gresch, M. Troyer, Air pollution in Mongolia: Policy brief, 2016.

[3] National Statistical Office of Mongolia, Population and housing by census of MongoliaNational report year of 2015, Ulaanbaatar, 2016. https://1212.mn/BookLibraryDownload.ashx?ur l=hun_am_oron_suutsnii_2015_toollogo_eng.p df $\& \ln =\mathrm{Mn}$.

[4] Mongolia accelerates Building Energy Efficiency Deep Dive Program, (n.d.). http://eastasia.iclei.org/new/latest/247.html (accessed March 13, 2021).

[5] WHO | WHO Guidelines for indoor air quality: household fuel combustion, WHO. (2018). http://www.who.int/airpollution/guidelines/hous ehold-fuel-combustion/en/ (accessed May 21, 2021).

[6] Ulaanbaatar Services Improvement Project, Ulaanbaatar Clean Air Project Third Quarter Report, 2018.

[7] S. Ishikawa, H. Hayama, E. Purev-Erdene, M. Enai, K. Kikuta, A. Kato, Survey report for indoor environment of settled down type ger in ger area, Ulaanbaatar, Mongolia, in: Summaries of Technical Papers of Annual Meeting, Hokkaido, 2007: pp. 53-54. https://eprints.lib.hokudai.ac.jp/dspace/bitstream /2115/50691/1/GKKD-2_53-54.pdf (accessed June 17, 2019).

[8] B. Buyantogtokh, Q. Zhang, Investigation on indoor thermal environment of the gers in Ulaanbaatar during winter (Studies on indoor environment and energy consumption of dwelling in Mongolia, Part 2), J. Environ. Eng. $\begin{array}{llll}\text { AIJ. } & 84 & \text { (2019) }\end{array}$ https://doi.org/10.3130/aije.84.245.

[9] Mongolian Agency for Standardization and Metrology, Mongolian national yurt MNS 0370:2003,

(2003). http://www.estandard.gov.mn.

[10] U. Purev, A. Hagishima, A field survey of traditional nomadic dwelling gers used as urban habitats in Ulaanbaatar, Mongolia, Evergreen. 7 (2020) https://doi.org/10.5109/4055214.

[11] Climate Data Online, (n.d.). https://www7.ncdc.noaa.gov/CDO/cdo (accessed August 23, 2021).

[12] Montsame, Coal price, (n.d.). https://www.montsame.mn/mn/read/172291 (accessed August 23, 2021).

[13] R. V. Dunkle, Configuration factors for radiant heat-transfer calculations involving people, J. Heat Transfer. 85 (1963) 71-76. https://doi.org/10.1115/1.3686012. 